\title{
Celebrating 20 years of SETAC German Language Branch (GLB)
}

\author{
Jochen P. Zubrod ${ }^{1 *}$, Rolf-Alexander Düring ${ }^{2}$, Klaus P. Ebke ${ }^{3}$, Dominic Englert ${ }^{4}$, Tobias Frische ${ }^{5}$, Bettina Hitzfeld ${ }^{6}$, \\ Marion Junghans ${ }^{7}$, Dominic Kaiser ${ }^{8}$, Anja Kehrer ${ }^{5}$, Silvio Knaebe ${ }^{9}$, Nadine Ruchter ${ }^{10}$ and Henner Hollert ${ }^{1{ }^{*}}$
}

\begin{abstract}
This editorial presents the objectives and achievements of the German Language Branch of the Society of Environmental Toxicology and Chemistry Europe (SETAC GLB), a regional branch of SETAC Europe, of the last 20 years. SETAC GLB serves Germany, Austria, and Switzerland, by providing an open forum for research related to ecotoxicology and environmental chemistry, to the sustainable management and regulation of natural resources, to education in environmental sciences, as well as to issues related to research and development, and manufacturing of chemicals and products. The editorial serves as an introduction for an article collection published in the journal Environmental Sciences Europe, providing an overview of the current state of ecotoxicology and environmental chemistry in Germanspeaking countries and of the main developments and key topics within SETAC GLB. The article collection was developed on the occasion of the 20th anniversary of the regional branch of SETAC Europe.
\end{abstract}

Keywords: Ecotoxicology, Environmental chemistry, SETAC, Anniversary

Dear readers

In 1996, the German Language Branch of the Society of Environmental Toxicology and Chemistry Europe (SETAC GLB) was inaugurated in Aachen, Germany. SETAC GLB serves Germany, Austria, and Switzerland, by providing an open forum for research related to ecotoxicology and environmental chemistry, to the sustainable management and regulation of natural resources, to education in environmental sciences, as well as to issues related to research and development, and manufacturing of chemicals and products. Alongside the annual meetings, a forum to discuss and exchange information, SETAC GLB's main activities are related to promoting young researchers and to increasing visibility of our field within science and society. Over two decades, SETAC GLB has become the leading scientific society in this field in the German-speaking countries.

\footnotetext{
*Correspondence: zubrod@uni-landau.de;

henner.hollert@bio5.rwth-aachen.de

${ }^{1}$ Institute for Environmental Sciences, University of Koblenz-Landau,

Landau, Germany

${ }^{11}$ Institute for Environmental Research, RWTH Aachen University, Aachen, Germany

Full list of author information is available at the end of the article
}

Our annual meetings are a well-known and wellattended platform, not only for experienced members, but also particularly for young scientists to present the results of their Master and Ph.D. theses as well as to enter into discussion and establish contacts with more seasoned members of the Society (see also the editorial of the SETAC Europe Students Advisory Council (SAC), this issue, Box 1, [1]). We are also able to present an award, once per year, for the best Master and Ph.D. thesis in ecotoxicology completed in a German-speaking country. In this context, another major focus of our effort to promote the next generation of scientists is the postgraduate degree program in ecotoxicology, which is jointly organized by SETAC GLB and GDCh (Gesellschaft Deutscher Chemiker e.V.) group 'Environmental chemistry and ecotoxicology' (cf. Ebke et al., this issue, Box 1, [2]). To date, the program looks back on a more than 10-year success story: from the start, courses had an average enrollment rate of $90 \%$, and the vast majority of employment-seeking graduates from the first courses succeeded in quickly finding a job related to their training. With over 450 students enrolled and graduates now working in academia, business, and government, the degree program can be considered a cornerstone of 
education for ecotoxicologists and environmental chemists in Germany, Austria, and Switzerland. However, despite these successes in promoting young researchers, all is not yet rosy in our research landscape. Recently, Martin Scheringer (this issue; Box 1, [3]) analyzed the current situation concerning the standing of ecotoxicology and environmental chemistry in the academic system with a special focus on Germany and Switzerland.

\section{Box 1: Articles from the article collection "20 years of SETAC GLB" and active links to the related pdf files}

- Lüderwald S, Newton K, Heye K, Bitter K, Moeris S, Benner L, Böhm P, Koch J, Feckler A, Castro M, Erikkson A (2018) SETAC GLB and SETAC SAC, a liaison promoting the next generation of ecotoxicologists and environmental chemists. https://doi. org/10.1186/s12302-018-0171-z.

- Ebke KP, Ahlers J, Braunbeck T, Oehlmann J, Ratte T, Schafer RB, Eisenträger A, Schäffer A (2016) The German postgraduate degree program in ecotoxicology (SETAC GLB and GDCh) a success story. https://doi.org/10.1186/s12302-016-0078-5.

- Scheringer M (2017) Environmental chemistry and ecotoxicology: in greater demand than ever. https:// doi.org/10.1186/s12302-016-0101-x.

- Brack W, Escher BI, Müller E, Schmitt-Jansen M, Schulze T, Slobodnik J, Hollert H (2018) Towards a holistic and solution-oriented monitoring of chemical status of European water bodies: how to support the EU strategy for a non-toxic environment? https ://doi.org/10.1186/s12302-018-0161-1.

- Frische T, Egerer S, Matezki S, Pickl C, Wogram J (2018) 5-Point programme for sustainable plant protection. https://doi.org/10.1186/s12302-0180136-2.

- Gallo F, Fossi C, Weber R, Santillo D, Sousa J, Ingram I, Nadal A, Romano D (2018) Marine litter plastics and microplastics and their toxic chemicals components: the need for urgent preventive measures. https://doi.org/10.1186/s12302-018-0139-z.

- Bandow N, Gartiser S, Ilvonen O, Schoknecht U (2018) Evaluation of the impact of construction products on the environment by leaching of possibly hazardous substances. https://doi.org/10.1186/ s12302-018-0144-2.

- Bundschuh M, Filser J, Lüderwald S, McKee MS, Metreveli G, Schaumann GE, Schulz R, Wagner S (2018) Nanoparticles in the environment: where do we come from, where do we go to? https://doi. org/10.1186/s12302-018-0132-6.
- Legradi JB, Di Paolo C, Kraak MHS, van der Geest HG, Schymanski EL, Williams AJ, Dingemans MML, Massei R, Brack W, Cousin X, Begout M-L, van der Oost R, Carion A, Suarez-Ulloa V, Silvestre F, Escher BI, Engwall M, Nilén G, Keiter SH, Pollet D, Waldmann P, Kienle C, Werner I, Haigis A-C, Knapen D, Vergauwen L, Spehr M, Schulz W, Busch W, Leuthold D, Scholz S, vom Berg C, Basu N, Murphy CA, Lampert A, Kuckelkorn J, Grummt T, Hollert H (2018) An ecotoxicological view on neurotoxicity assessment. https://doi.org/10.1186/ s12302-018-0173-x.

- Weber R, Herold C, Hollert H, Kamphues J, Blepp M, Ballschmiter K (2018) Reviewing the relevance of dioxin and PCB sources for food from animal origin and the need for their inventory, control and management. https://doi.org/10.1186/s12302-0180166-9.

- Rehberger K, Kropf C, Segner H (2018) In vitro or not in vitro: a short journey through a long history. https://doi.org/10.1186/s12302-018-0151-3.

- von der Trenck KT, Konietzka R, Biegel-Engler A, Brodsky J, Hadicke A, Quadflieg A, Stockerl R, Stahl T (2018) Significance thresholds for the assessment of contaminated groundwater: perfluorinated and polyfluorinated chemicals. https://doi.org/10.1186/ s12302-018-0142-4.

- Werner I (2018) The Swiss Ecotox Centre: bridging the gap between research and application. https:// doi.org/10.1186/s12302-018-0147-z.

- Duis K, Coors A (2016) Microplastics in the aquatic and terrestrial environment: sources (with a specific focus on personal care products), fate and effects. https://doi.org/10.1186/s12302-015-0069-y.

- Beermann AJ, Zizka VMA, Elbrecht V, Baranov V, Leese F (2018) DNA metabarcoding reveals the complex and hidden responses of chironomids to multiple stressors. https://doi.org/10.1186/s1230 2-018-0157-x.

- Brendel S, Fetter E, Staude C, Vierke L, BiegelEngler A (2018) Short-chain perfluoroalkyl acids: environmental concerns and a regulatory strategy under REACH. https://doi.org/10.1186/s1230 2-018-0134-4.

- Coors A, Vollmar P, Heim J, Sacher F, Kehrer A (2018) Environmental risk assessment of biocidal products: identification of relevant components and reliability of a component-based mixture assessment. https://doi.org/10.1186/s12302-018-0134-4.

- Hartmann S, Klaschka U (2018) Do consumers care about substances of very high concern in articles? https://doi.org/10.1186/s12302-018-0153-1. 
- Hennecke D, Bauer A, Herrchen M, Wischerhoff E, Gores F (2018) Cationic polyacrylamide copolymers (PAMs) environmental half life determination in sludge-treated soil. https://doi.org/10.1186/s1230 2-018-0143-3.

- Kuhr S, Schneider S, Meisterjahn B, Schlich K, Hund-Rinke K, Schlechtriem C (2018) Silver nanoparticles in sewage treatment plant effluents: chronic effects and accumulation of silver in the freshwater amphipod Hyalella azteca. https://doi. org/10.1186/s12302-018-0137-1.

- Müller ME, Escher BI, Schwientek M, Werneburg M, Zarfl C, Zwiener C (2018) Combining in vitro reporter gene bioassays with chemical analysis to assess changes in the water quality along the Ammer River, Southwestern Germany. https://doi. org/10.1186/s12302-018-0148-y.

- Niehus NC, Schafer S, Mohlenkamp C, Witt G (2018) Equilibrium sampling of HOCs in sediments and suspended particulate matter of the Elbe River. https://doi.org/10.1186/s12302-018-0159-8.

- Schweizer M, Dieterich A, Corral Morillas N, Dewald C, Miksch L, Nelson S, Wick A, Triebskorn R, Kohler HR (2018) The importance of sediments in ecological quality assessment of stream headwaters: embryotoxicity along the Nidda River and its tributaries in Central Hesse, Germany. https://doi. org/10.1186/s12302-018-0150-4.

- Seidensticker S, Grathwohl P, Lamprecht J, Zarfl C (2018) A combined experimental and modeling study to evaluate $\mathrm{pH}$-dependent sorption of polar and non-polar compounds to polyethylene and polystyrene microplastics. https://doi.org/10.1186/ s12302-018-0155-z.

- Crawford SE, Hartung T, Hollert H, Mathes B, van Ravenzwaay B, Steger-Hartmann T, Studer C, Krug HF (2017) Green Toxicology: a strategy for sustainable chemical and material development. https:// doi.org/10.1186/s12302-017-0115-z.

- Jänsch S, Bauer J, Leube D, Otto M, Römbke J, Teichmann H, Waszak K (2018) A new ecotoxicological test method for Genetically Modified Plants and other stressors in soil with the black fungus gnat Bradysia impatiens (Diptera) Current status of test development and dietary effects of azadirachtin on larval development and emergence rate. https:// doi.org/10.1186/s12302-018-0167-8.

- Zimmer EI, Preuss TG, Norman S, Minten B, Ducrot V (2018) Modelling effects of time-variable exposure to the pyrethroid beta-cyfluthrin on rainbow trout early lifestages. https://doi.org/10.1186/ s12302-018-0162-0.
- Rybicki M \& Jungmann D (2018) Direct and indirect effects of pesticides on a benthic grazer during its life cycle. https://doi.org/10.1186/s12302-0180165-x.

- Andrä J, Beyer F, Cornelissen G, Einfeldt J, Heseding J, Kümmerer K, Oelkers K, Floeter C (2018) PharmCycle: a holistic approach to reduce the contamination of the aquatic environment with antibiotics by developing sustainable antibiotics, improving the environmental risk assessment of antibiotics, and reducing the discharges of antibiotics in the wastewater outlet. https://doi.org/10.1186/s12302-0180156-y.

- Wilhelm S, Jacob S, Ziegler M, Köhler H-R, Triebskorn R (2018) Influence of different wastewater treatment technologies on genotoxicity and dioxinlike toxicity in effluent-exposed fish. https://doi. org/10.1186/s12302-018-0154-0.

- Schäffer A, Kästner M, Trapp S (2018) A unified approach for including non-extractable residues (NER) of chemicals and pesticides in the assessment of persistence. https://doi.org/10.1186/s1230 2-018-0181-x.

- Lehmann R, Bachmann J, Karaoglan B, Lacker J, Lurman G, Polleichtner C, Ratte HT, Ratte M (2018) The CPCAT as a novel tool to overcome the shortcomings of NOEC/LOEC statistics in ecotoxicology: a simulation study to evaluate the statistical power. https://doi.org/10.1186/s12302-018-0178-5.

- Wong JWY, Hitzfeld B, Zimmermann M, Werner I, Ferrari BJD (2018) Current developments in soil ecotoxicology and the need for strengthening soil ecotoxicology in Europe: results of a stakeholder workshop. https://doi.org/10.1186/s12302-0180180-y.

- Reeg J, Heine S, Mihan C, McGee S, Preuss TG, Jeltsch F (2018) Simulation of herbicide impacts on a plant community: comparing model predictions of the plant community model IBC-grass to empirical data. https://doi.org/10.1186/s12302-018-01749.

- Velki M, Lackmann C, Barranco A, Ereño Artabe A, Rainieri S, Hollert H, Seiler T-B (2019) Pesticides diazinon and diuron increase glutathione levels and affect multixenobiotic resistance activity and biomarker responses in zebrafish (Danio rerio) embryos and larvae. https://doi.org/10.1186/s1230 2-019-0186-0.

His analysis indicates that although there is a great demand for innovative research and teaching in ecotoxicology and environmental chemistry, the relevance 
and reputation of these disciplines in the academic system have been decreasing for years. To tackle many of the most pressing, current environmental issues (many of which are presented in review or discussion papers of this issue; Box 1), it is, however, crucial that our field remains well-rooted in academic science and is provided with sufficient equipment, resources, and prospects for development. Moreover, as many environmental issues (also those related to contaminants) are multifaceted and thus require to be addressed jointly by ecotoxicologists and environmental chemists from differing specializations, more large collaborative research projects/ consortia need to be supported by major funding bodies such as the Federal Ministry of Education and Research (BMBF, Bundesministerium für Bildung und Forschung) or the German Research Foundation (DFG, Deutsche Forschungsgemeinschaft). In this context, a major step for our community was the right for SETAC GLB to nominate colleagues for the review board of the DFG in 2017. This puts our discipline on the map for reviewers of project proposals in a major German funding agency.

In addition to this academic recognition, a number of important topics in our field, such as regulation of glyphosate, dioxins, and PCBs in food [4], neuro(eco)toxicity [5], nanoparticles, or microplastics, are discussed on an everyday basis in newspapers as well as other media and have moved to the center of political attention. In this context, the recent National Academy of Sciences Leopoldina publication "The Silent Spring-On the need for sustainable plant protection" [6] authored by a consortium of experts in the field will be an important basis for discussion and discourse. The authors point out that alongside other drivers of global change, plant protection products contribute to the dramatic loss of biodiversity.

However, although many of the topics dealt with by ecotoxicologists and environmental chemists are recognized as being of global significance, well-founded, unbiased information rarely finds its way to the public. Therefore, an ad-hoc meeting on how to communicate important issues and research results to society was held during the 21st SETAC GLB annual meeting in Tübingen, Germany, in 2016. The participants decided to organize a workshop involving scientists representing SETAC's tripartite structure (i.e., academia, business, and government) as well as media specialists. The workshop was held in Hirschberg, Germany, in November 2017. Views and perspectives on science and risk communication were discussed to initiate a broader discussion in SETAC GLB and the GDCh on the communication of research findings from our discipline. As an outcome of the meeting it was agreed that (1) the discussions on public communication and transfer of our knowledge to society should be increased; (2) ecotoxicologists and environmental chemists from German-speaking countries should apply jointly for coordinated large-scale research funding programs; and (3) a joint platform for sharing knowledge on environmental contaminants via movie clips, press material, and virtual reality concepts should be developed.

To mark our 20 years of activity, we decided to publish a collection of publications in Environmental Sciences Europe (ESEU) - as we did to celebrate SETAC GLB's 10th anniversary (https://www.setac-glb.de/fileadmin/ setac/redakteure/uwsf19s_1_2007_small.pdf)_providing an overview of the current state of ecotoxicology and environmental chemistry in German-speaking countries and the main developments and key topics within SETAC GLB over the past 3 years. The open access articles are published in our co-operating journal ESEU and can be accessed via the following link: https://www.springerop en.com/collections/20-years-SETAC-GLB. In addition, this collection will be published as a book, for those preferring the traditional style of a paper-based publication. We are happy that we were able to attract authors from academia, business, and government, thus representing SETAC's tripartite structure. With these publications, we would like to invite you, dear readers, to join a critical and constructive discussion about the development and relevance of our disciplines and SETAC GLB to science and society. The articles [i.e., (critical) reviews as well as discussion and research papers] provide a broad basis for such dialogue and Box 1 gives an overview of the articles in this special issue. For instance, the need for holistic and solution-oriented monitoring of the chemical status of European water bodies [7] and urgent preventive measures with respect to marine litter plastics and microplastics [8], current developments in the evaluation of nanoparticles [9], soil ecotoxicology [10], in vitro methods [11], and sustainable plant protection [12] are discussed.

Finally, we would like to express our deepest gratitude to all those who have contributed to SETAC GLB over the last 20 years including all authors and reviewers for making this article collection possible. All activities mentioned above can only flourish because of the pluralism of expertise (well-represented also by the greetings by representatives of academia, business, and government; boxes 2, 3, and 4) and opinions present in our society, which is why we rely on the feedback and input we receive from you, our members. Furthermore, we thank the sponsors mentioned in this issue for their financial support. We will be happy to welcome you at the 24th SETAC GLB annual meeting in Landau, Germany, in 2019 and are looking forward to discussing with you the future of our field and SETAC GLB. The board of SETAC GLB and editors of this article collection (Fig. 1) 


\section{Box 2: Greeting by Prof. Dr. Rik Eggen, Deputy Director of Eawag}

Environmental sciences have played a major role in environmental policy discussions in Switzerland over the past decades. Due to the increased demand of federal and cantonal authorities for services in ecotoxicology, the Swiss Centre for Applied Ecotoxicology was founded in 2008 and is being hosted jointly by Eawag (Swiss Federal Institute of Aquatic Science and Technology) and the EPFL (École polytechnique fédérale de Lausanne) [13]. Almost simultaneously with the founding of SETAC GLB in 1998, the Swiss Water Protection Ordinance (GSchV) was adopted. Its purpose is to protect water bodies from adverse impacts and to facilitate sustainable water use. The GSchV is not a static document but is regularly adapted to findings from environmental research. Milestones in 1998 were the definition of numerical requirements for selected heavy metals $(\mathrm{Pb}, \mathrm{Cd}, \mathrm{Cr}, \mathrm{Cu}, \mathrm{Ni}, \mathrm{Hg}$, and $\mathrm{Zn}$ ) based on the ecotoxicological effect of these metals [14]. Another milestone, probably the largest to date, is the setting of purification targets for organic trace substances in wastewater treatment plants. Since 2016, selected wastewater treatment plants have had to reduce the concentration of organic trace substances (e.g., drugs such as diclofenac or industrial chemicals such as benzotriazole) contained in raw wastewater by $80 \%$. The associated expansion of selected wastewater treatment plants by a fourth treatment stage has made Switzerland a European pioneer in wastewater treatment. These measures are financed by a levy of 9 Swiss francs per year from each Swiss inhabitant connected to a wastewater treatment plant. The ground works were laid by more than 10 years of interdisciplinary environmental scientific research in the fields of ecotoxicology, environmental chemistry, urban water management, and process engineering (https://www.micropoll.ch/de/dokumente/berichte/) [15]. Ecotoxicological in-vitro tools and biotests, analytical chemistry and field biotests were developed to show that, depending on the local conditions, ozonation, or active charcoal as additional treatment steps were effective to reach the goals. Through the various projects performed to improve water quality, as well as the political and public debate about the upgrading of wastewater treatment plants, the Swiss public became even more aware of environmental issues and has accepted the additional costs.

The first studies revealed a great suitability of advanced wastewater treatment methods to reduce the micropollutant load substantially. However, some ongoing studies in the EU project SOLUTIONS confirmed that upgrading WWTPs will not completely reduce the micropollutant burden [16]. Further or combined treatments, or measures at the source will be required to avoid that micropollutants enter the aquatic environment via wastewater.

Such successes motivate us environmental scientists to continue our work, and we cannot rest on our laurels from the past. For the future, we need a holistic view of chemical substance flows and their impacts in all environmental compartments, including sediments, soils and air, and even including human health. This in interdisciplinary efforts in close collaboration with various stakeholders.

With this look into the future, I would like to express my sincere thanks to SETAC GLB for your big contribution to environmental toxicology and chemistry and for your support to the development of young professionals. I am convinced that Swiss scientists and Eawag will be happy to contribute to the success in the next 20 years.

\section{Box 3: Greeting by Dr. G. Peter Dohmen, a founder member of SETAC GLB and principal expert in the Global Ecotoxicology department at BASF Agricultural Solutions}

Over 20 years ago, it was my pleasure and honour to be part of the founding board of the SETAC GLB. We wanted to apply the successful global SETAC concept in German-speaking countries. Our aim was to enable simplified processes, faster and more direct communication, and the stronger integration of young scientists at lower costs within this more defined geographical unit as compared to the larger international organisation. The present anniversary of SETAC GLB is a nice proof of this concept.

GLB is dedicated to the study, analysis, and solution of environmental problems, and since its foundation has worked very successfully to implement the overall SETAC goals and vision for the protection, promotion, and management of sustainable environmental quality and ecosystem integrity. For this purpose, SETAC fosters the advancement and application of scientific research using multidisciplinary approaches with scientists from backgrounds that reflect its tripartite structure (academia, government, and industry). SETAC conferences and workshops frequently bring forward previously unknown environmental issues, but equally develop proposals on how to address and evaluate such issues and provide options for risk mitigation. This is a significant contribution to the development of well-founded and sustainable solutions 


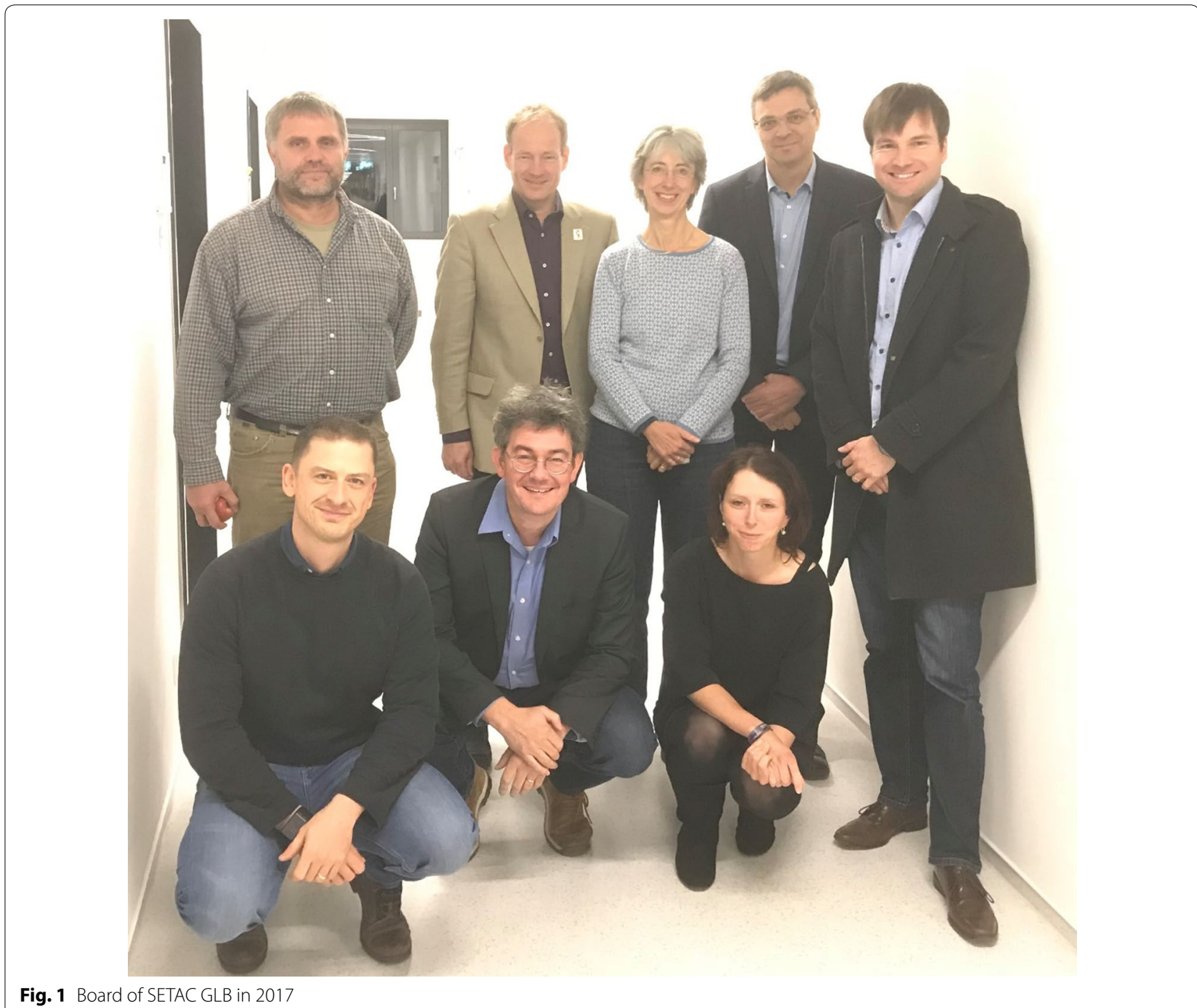

for environmental issues. Unfortunately, there are tendencies to undermine this successful concept by labelling science and scientists as either "good" (trustworthy) or "bad" based on the background and not on the science, instead of providing solution orientated proposals based on transparency and cooperation. As a consequence, we face very controversial statements and diminishing societal trust towards scientific statements in general. I very much hope that SETAC GLB will also in future manage to confine controversies to the necessary scientific debates and contribute to consensus-orientated problem solutions. Transparency, easy access to information and solid scientific work should be the basis for this. In this context, I would like to praise the efforts of SETAC GLB in the education and training of certified ecotoxicologists, through the estimable commitment of many highly qualified environmental scientists from different institutions. Part of the success of SETAC GLB is also due to its philosophy of 'diversity and inclusion'. Not only do we have a rather fair gender distribution (which unfortunately was not yet the case at the time of the founding board) with male and female scientists from different scientific fields, we also have a good mix of established scientists and promising young researchers. Therefore, I have no doubt about the continued future success of SETAC GLB and for this I wish all the best.

\section{Box 4: Greeting by Maria Krautzberger, President of the German Environment Agency (UBA), Dessau-Rosslau}

The 20th anniversary of SETAC GLB e.V. marks not just 20 years of scientific dialogue on equal terms between 
authorities, industry and the scientific community, but also 20 years of promoting young scientists in the fields of ecotoxicology and environmental chemistry.

The tripartite structure of the SETAC GLB, as well as the extraordinary engagement of its members helped the society gaining national and international respect and notoriety.

The promotion of research, teaching and education in the fields of ecotoxicology and environmental chemistry were and still are consistently pursued. These activities at national level are integrated in the European and global network of the parent society SETAC.

With this structure, SETAC GLB opens opportunities for an intense exchange on regional questions without neglecting the European and worldwide perspectivesan aspect which is increasingly more important. The annual conferences offer, especially young scientists, the opportunity to present their results for the first time to a broader expert audience and to establish contacts for their future academic career. The annually advertised, highly remunerated young scientist award is an important element of the society's promotion program, for young researchers as well.

Only well-educated experts are typically in a position to implement and further develop complex legal requirements. This is only possible in dialogue with regulatory authorities, industry and the scientific community. One successful example of a fruitful collaboration is the post-gradual training course system 'Certified Ecotoxicologist' developed by SETAC GLB together with the German Chemical Society (Gesellschaft Deutscher Chemiker, GDCh) which has considerably improved the education of young scientists in German-speaking countries.

In SETAC GLB, experts from different stakeholder groups are equally represented. Since the foundation of the society, UBA has been involved in SETAC's GLB board, the annual meetings and post-gradual training courses.

I would like to extend my best wishes to SETAC GLB for their future work. I look forward to the continuation of many fruitful dialogues for the protection of the (our) environment.

\section{Authors' contributions}

JZ and $\mathrm{HH}$ conceptualized the manuscript. RAD, KPE, DE, TF, BH, MJ, DK, AK, $S K$, and NR contributed specific aspects to the manuscript and improved the manuscript content. All authors read and approved the final manuscript.

\section{Author details}

${ }^{1}$ Institute for Environmental Sciences, University of Koblenz-Landau, Landau, Germany. ${ }^{2}$ Institute of Soil Science and Soil Conservation, Justus Liebig University, Giessen, Germany. ${ }^{3}$ Institut für Gewässerschutz Mesocosm GmbH,
Homberg (Ohm), Germany. ${ }^{4}$ RIFCON GmbH, Hirschberg, Germany. ${ }^{5}$ German Environment Agency (Umweltbundesamt, UBA), Dessau-Rosslau, Germany. ${ }^{6}$ Federal Office for the Environment, Bern, Switzerland. ${ }^{7}$ Swiss Centre for Applied Ecotoxicology, Dübendorf, Switzerland. ${ }^{8}$ BASF SE, Limburgerhof, Germany. ${ }^{9}$ Eurofins Agroscience Services EcoChem GmbH, Niefern-Öschelbronn, Germany. ${ }^{10}$ Institute of Aquatic Ecology, University of Duisburg-Essen, Essen, Germany. ${ }^{11}$ Institute for Environmental Research, RWTH Aachen University, Aachen, Germany.

\section{Acknowledgements}

We like to thank Carol Sizmur for improving the English language of this manuscript

\section{Competing interests}

The authors declare that they have no competing interests. HH is Editor-inChief of this Journal.

\section{Availability of data and materials}

Not applicable.

\section{Consent for publication}

Not applicable.

Ethics approval and consent to participate

Not applicable.

\section{Publisher's Note}

Springer Nature remains neutral with regard to jurisdictional claims in published maps and institutional affiliations.

Received: 16 January 2019 Accepted: 22 January 2019

Published online: 07 February 2019

\section{References}

1. Lüderwald S, Newton K, Heye K, Bitter K, Moeris S, Benner L, Bohm P, Koch J, Feckler A, Castro M, Erikkson A (2018) SETAC GLB and SETAC Europe SAC: a liaison promoting the next generation of ecotoxicologists and environmental chemists. Environ Sci Eur 30:41

2. Ebke KP, Ahlers J, Braunbeck T, Oehlmann J, Ratte T, Schäfer RB, Eisenträger A, Schäffer A (2016) The German postgraduate degree program in ecotoxicology (SETAC GLB and GDCh): a success story. Environ Sci Eur 28:19

3. Scheringer M (2017) Environmental chemistry and ecotoxicology: in greater demand than ever. Environ Sci Eur 29:3

4. Weber R, Herold C, Hollert H, Kamphues J, Blepp M, Ballschmiter K (2018) Reviewing the relevance of dioxin and PCB sources for food from animal origin and the need for their inventory, control and management. Environ Sci Eur 30:42

5. Legradi JB, Di Paolo C, Kraak MHS, van der Geest HG, Schymanski EL, Williams AJ, Dingemans MML, Massei R, Brack W, Cousin X, Begout M-L, van der Oost R, Carion A, Suarez-Ulloa V, Silvestre F, Escher BI, Engwall M, Nilén G, Keiter SH, Pollet D, Waldmann P, Kienle C, Werner I, Haigis A-C, Knapen D, Vergauwen L, Spehr M, Schulz W, Busch W, Leuthold D, Scholz S, vom Berg C, Basu N, Murphy CA, Lampert A, Kuckelkorn J, Grummt T, Hollert H (2018) An ecotoxicological view on neurotoxicity assessment. Environ Sci Eur 30:46

6. Schäffer A, Filser J, Frische T, Gessner M, Köck W, Kratz W, Liess M, Nuppenau, E-A, Roß-Nickoll M, Schäfer R, Scheringer M (2018) The silent spring —on the need for sustainable plant protection. Leopoldina Discussions No 16,61

7. BrackW, Escher BI, Müller E, Schmitt-Jansen M, Schulze T, Slobodnik J, Hollert H (2018) Towards a holistic and solution-oriented monitoring of chemical status of European water bodies: how to support the EU strategy for a non-toxic environment? Environ Sci Eur 30:33

8. Gallo F, Fossi C, Weber R, Santillo D, Sousa J, Ingram I, Nadal A, Romano D (2018) Marine litter plastics and microplastics and their toxic chemicals components: the need for urgent preventive measures. Environ Sci Eur 30:13 
9. Bundschuh M, Filser J, Luderwald S, McKee MS, Metreveli G, Schaumann GE, Schulz R, Wagner S (2018) Nanoparticles in the environment: where do we come from, where do we go to? Environ Sci Eur 30:6

10. Wong JWY, Hitzfeld B, Zimmermann M, Werner I, Ferrari BJD (2018) Current developments in soil ecotoxicology and the need for strengthening soil ecotoxicology in Europe: results of a stakeholder workshop. Environ Sci Eur 30:49

11. Rehberger K, Kropf C, Segner H (2018) In vitro or not in vitro: a short journey through a long history. Environ Sci Eur 30:23

12. Frische T, Egerer S, Matezki S, Pickl C, Wogram J (2018) 5-Point programme for sustainable plant protection. Environ Sci Eur 30:8

13. Werner I (2018) The Swiss Ecotox Centre: bridging the gap between research and application. Environ Sci Eur 30:15
14. Behra R (1993) In vitro effects of cadmium, zinc and lead on calmodulindependent actions in Oncorhynchus mykiss, Mytilus sp., and Chlamydomonas reinhardtii. Arch Environ Contam Toxicol 24:21-27

15. Eggen RIL, Hollender J, Joss A, Schärer M, Stamm C (2014) Reducing the discharge of micropollutants in the aquatic environment: the benefits of upgrading wastewater treatment. Environ Sci Technol 48:7683-7689

16. Neale PA, Munz NA, Ait-Aissa S, Altenburger R, Brion F, Busch W, Escher BI, Hilscherova K, Kienle C, Novak J, Seiler T-B, Shao Y, Stamm C, Hollender $J(2017)$ Integrating chemical analysis and bioanalysis to evaluate the contribution of wastewater effluent on the micropollutant burden in small streams. Sci Total Environ 576:785-795

\section{Submit your manuscript to a SpringerOpen ${ }^{\odot}$ journal and benefit from:}

- Convenient online submission

- Rigorous peer review

- Open access: articles freely available online

- High visibility within the field

- Retaining the copyright to your article

Submit your next manuscript at $\boldsymbol{\nabla}$ springeropen.com 